\title{
Menopause in Women With HIV Infection: An Interesting But Neglected Issue in Peruvian Research Agenda
}

\author{
Jose Arriola-Montenegro $^{1 *}$, Victor Cutimanco-Pacheco' ${ }^{1}$, Edward Mezones-Holguin ${ }^{2}$
}

\section{Dear Editor,}

We have read with interest the article written by Andany et al (1), in which they explain important aspects of the menopausal transition in Women with HIV. The most relevant key points described were the positive effects of highly active anti-retroviral therapy (HAART) on those patients, being one of them, the increasing survival and subsequent higher frequency of women in middle-age period. Therefore, this particular context has allowed to carry out further research about menopausal transition in women with HIV (2).

They described that a high proportion of women with HIV have symptoms of premature menopause, than females without HIV; for example a decrease bone mineral density and more quality life impairment (due to climacteric symptomatology). These findings are relevant because this body of evidence could be a basis for proposing a holistic clinical approach and multidisciplinary management of climacteric period in women with HIV. Moreover, negative consequences in several areas of health must be explored in this women's life stage. For example, the premature menopause and its negative repercussion on cardiovascular risk, among others $(3,4)$.

Beyond the interesting conclusions reviewed, it is important to take in consideration that the evidence analyzed by the authors is primarily from the United States and Brazil, so it is necessary to study the primary evidence from other Latin-American countries. In that sense, the study of menopause in HIV patients in Peru should be of great importance. Especially when in 2013 around $72000 \mathrm{HIV}$ cases were reported, where 21000 were women over 30 years old, who would be exposed to hormonal changes including premature menopause (5). Nevertheless, scientific publications about menopause in women with HIV are scarce in Peru, and exploration of climacteric in these patients is uncommon in clinical practice. Consequently, to propose and lead policies that encourage the development of scientific research in this area is essential. Moreover, these policies should focus on the comprehensive assessment of women with HIV, where the hormonal evaluation must be included as part of a multidisciplinary approach.

\section{Conflict of Interests}

Authors declare that they have no conflict of interests.

\section{Ethical Issues}

Not applicable.

\section{Financial Support}

None.

\section{References}

1. Andany N, Kennedy VL, Aden M, Loutfy M. Perspectives on menopause and women with HIV. Int J Womens Health. 2016;8:1-22. doi: 10.2147/IJWH.S62615.

2. Tariq S, Delpech V, Anderson J. The impact of the menopause transition on the health and wellbeing of women living with HIV: A narrative review. Maturitas. 2016;88:76-83. doi: 10.1016/j.maturitas.2016.03.015.

3. Kanapathipillai R, Hickey M, Giles M. Human immunodeficiency virus and menopause. Menopause. 2013;20(9):983-90.

4. Conde DM, Silva ET, Amaral WN, et al. HIV, reproductive aging, and health implications in women: a literature review. Menopause. 2009;16(1):199-213.

5. Murray CJ, Ortblad KF, Guinovart C, et al. Global, regional, and national incidence and mortality for HIV, tuberculosis, and malaria during 1990-2013: a systematic analysis for the Global Burden of Disease Study 2013. Lancet. 2014;384(9947):1005-70. doi: 10.1016/S01406736(14)60844-8.

\footnotetext{
(C) 2018 The Author (s); This is an open-access article distributed under the terms of the Creative Commons Attribution License (http://creativecommons.org/licenses/by/4.0), which permits unrestricted use, distribution, and reproduction in any medium, provided the original work is properly cited.
} 